\title{
THE PERSONAL FINANCE BUSINESS UNDER REGULATION
}

\author{
Winliam Trutant Foster*
}

The borrower's first line of defense against the loan shark is the licensed personal finance company. This will be evident from the statistics which follow. They show that, to a far greater extent than any other cash-lending agency, the licensed personal finance company invades the loan shark's own territory. Indeed, it was for the express purpose of making this assault possible that the Uniform Small Loan Law was drafted thirty years ago. Further proof is furnished by the loan sharks themselves. They attack only the licensed lenders and the laws under which they operate. In Kentucky, the leaders among the loan sharks even went so far, in attempting to prevent passage of the Uniform Small Loan Law, as to say to their brethren, "We all know that such a law will put us all out of business."

For the present purpose, therefore, in our discussion of money-lending under regulation, we shall deal mainly with licensed personal finance companies. There is, to be sure, one other rigidly regulated agency-the credit union-which also carries its offensive into the very fields where the illegal lenders do most damage. The credit union is indispensable. Every month it makes small loans to thousands of potential victims of the outlaws, and at rates substantially lower than this class of borrowers could get from any commercial agency. However, as shown in Chart I, the volume of business of personal finance companies is several times as large as that of credit unions. In any event, we cannot here cover the operations of all the regulated and partially regulated makers of consumer loans. We shall consider mainly that agency which now does the most, wherever the laws permit, to thwart the ancient practice of usury by providing a legal source of small loans.

From the regulated personal finance companies more than two million individuals, in a few more than half the states, have borrowed money during the past year. Moreover, it seems probable that of all wage earners and of all families not living on farms, about one out of five obtained loans, within the past three or four years, from licensed personal finance companies. ${ }^{1}$ The greater part of the business

- A.B., rg0r, A.M., r904, Harvard University; Ph.D., r9r r, Columbia University. Director, Pollak Foundation for Economic Research. Chairman, Committee on Consumer Credit, Commonwealth of Massachusetts. Former president, Reed College. Author, Loan Sharks and Their Victims (Pub. Affairs Committee, 1940), and numerous other works on economic subjects.

2 "More than 2,300,000 families, or over 9 per cent of all the non-relief families in the United States, were indebted for cash loans in the year x935-36." Bernerenn, The Patrens of Consumen Dent, r935-36. (Nat'l. Bur. Econ. Res. I940) 52. 
Chart I. Loan Balances of Cash-Lending Agencies IN the United States, 1923-37

Millions

of dollars

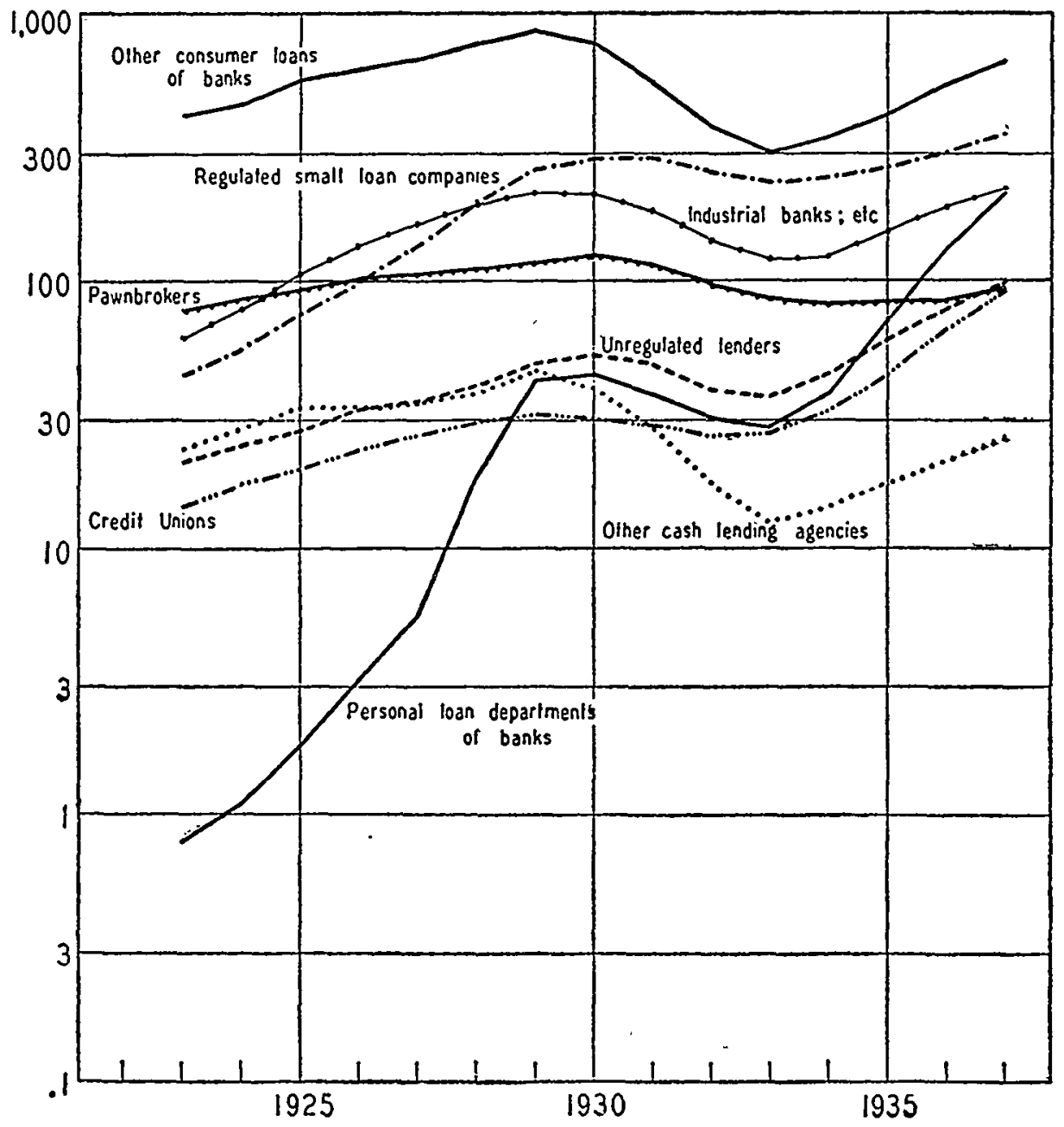

is concentrated in the industrial states; in nine of them, there are about three fourths of the licensed loan offices. These offices are owned and operated by individuals, partnerships and corporations; but in recent years corporatiors, have been doing a large proportion of the business. Today, these corporations have established lines of bank credit, and the largest of them also sell notes, stocks, and bonds in the open market.

\section{Who Lends Money to Consumers?}

The agencies which made cash loans to consumers in the United States from I923 to 1937 , inclusive, and the amounts of their loans outstanding at the end of each year, 
are shown in Chart I. ${ }^{2}$ A glance at the chart reveals rapid growth. In those 14 years, as a result of this growth and that of several other agencies, consumer debts mounted from about $\$ 4,800,000,000$ to about $\$ 8,300,000,000$, an increase of about $73 \%$. Nearly two thirds of this increase came from time sales by retailers and the business of sales finance companies. Of the rest, about $\$ 563,000,000$ resulted from loans by commercial banks; about \$rig,000,000 from loans by personal finance companies; about $\$ 100,000,000$ from loans by industrial banks; and about $\$ 66,000,000$ from loans by credit unions.

The growth of consumer debts. to cash-lending agencies during this period, compared with the growth of consumer debts to various other agencies, is shown in Chart II.

Continued growth of personal finance companies is reported by the United States Departiment of Commerce. ${ }^{3}$ Outstanding loan balances kept on rising during the first half of 1940. The volume at the end of June $(\$ 44 \mathrm{I}, 700,000)$ was $7.8 \%$ above December, 1939, and $20.7 \%$ above June, 1939. The $\$ 32,000,000$ net gain in outstanding loans from the end of December, 1939, to tha end of June, 1940, was. 6 r. $6 \%$ greater than the gain between the same dates of the previous year.

\section{To What Extent Are Cash-Lending Agencies Regulated?}

Of all the consumer cash lending agencies, the only ones which are now adequately and specifically regulated in any state are credit unions and personal finance companies. Under the present laws, state and federal, credit unions are set up with sufficient protection of their borrowing and investing members. Chief among the other measures of control, and the only adequate one which has been tried for many years and is now operative in a majority of states, is the Uniform Small Loan Law, under which the personal finance companies are licensed. These are the only commercial, consumer credit agencies which have been subject to sufficient regulation and supervision, for a sufficient period of time, to furnish adequate statistics.

Supervision over other consumer credit agencies and rate regulations are insufficient. This is notoriously true of instalment sellers and of instalment sales finance companies. Alone among the states, Indiana (1935) and Wisconsin (1935) have special statutes which are far-reaching in the field of instalment selling and financing. Michigan (1939) with its new disclosure act covering motor vehicles has made a good start. The Maine law (1939) provides for the licensing of concerns which finance time sales of motor vehicles. Apart from these exceptional cases, the laws of the various states provide no protection for instalment buyers comparable to the protection provided for consumer borrowers under the Uniform Small Loan Law. Regula-

'Data from Nugent, Consumer Cremit and Economic Stability (Russell Sage Foundation, 1939). The same data, together with table of rates charged by various agencies, is given in Foster, Credit for Consumers (Public Affairs Committec, 1940) Pamphlet No. 5, Revised. For differences between estimates of consumer instalment credit by the National Bureau of Economic Research and estimates of all consumer credit by the Ruscell Sage Foundation, see the Bureau's study, Tre Volouge of Consumer Inetalment CoeDIT (1940) I3I.

- Personal Finance Companies-Instalment Loans to Consumers (Credit Analysis Unit, Marketing Research Div., U. S. Dep't Com., 1940). 
Chart II. Consumer Debts to Various Ágencies In the United States, r923-37*

Mlillions

of dollars

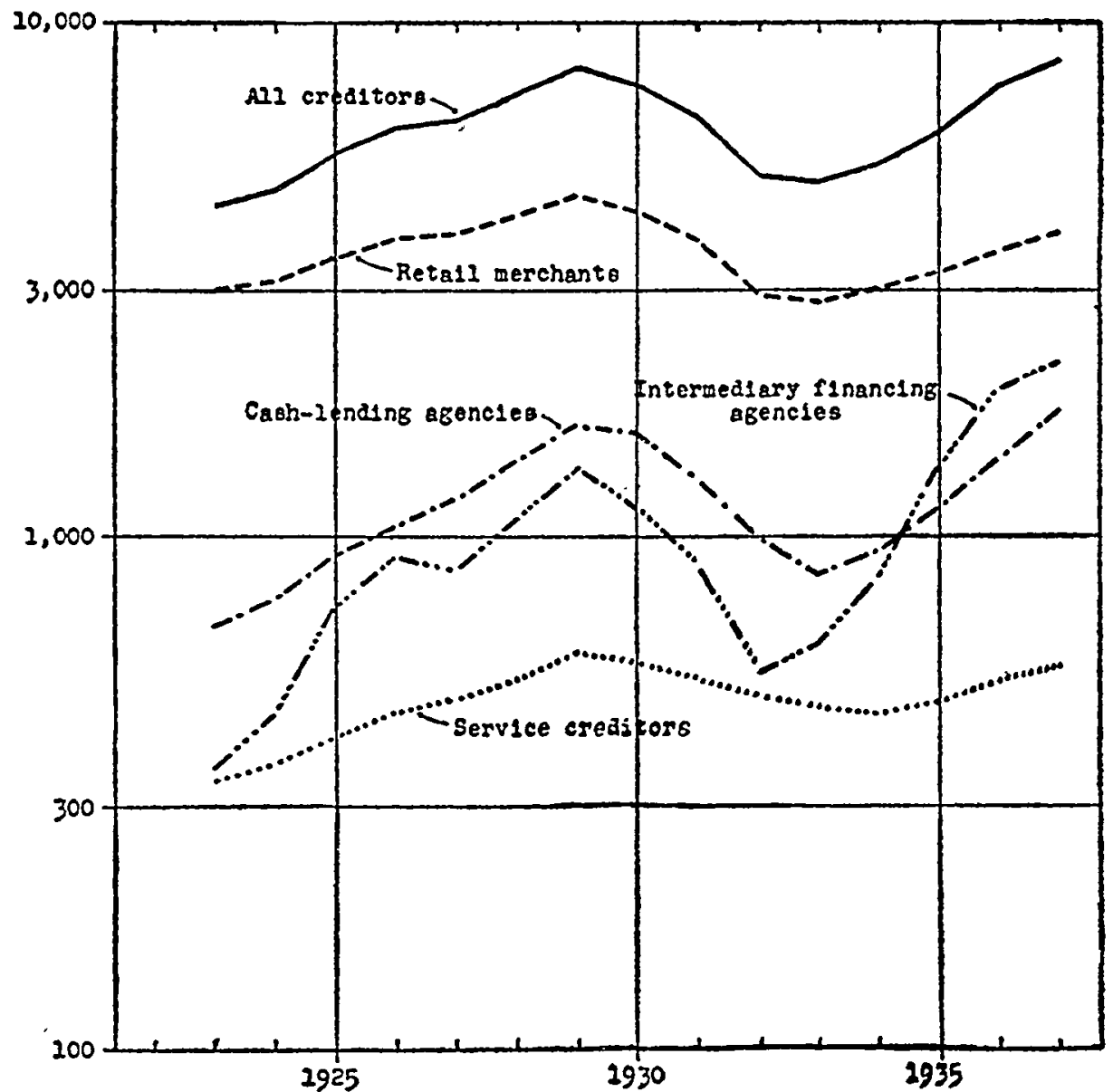

- Chart taken from Nugent, Consumer Credit and Economic Stability (Russell Sage Foundation, 1939).

tion of the time sales business is long overdue. Although the most flagrant abuses in this business are confined to the buccaneering minority of dealers, $15 \%$ at the most, there is widespread failure to state the total charges, at the time of sale, in a simple, perfectly clear way, which enables the buyer easily to compare the carrying charges with those of alternative, available methods of financing the purchase."

'Plummer and Young, Sales Finance Companies and Their Credit Practices (Nat'l Bur. Econ. Res., 1940), c. 9; Report of the Governor's Committee on Consumer-Credit (Mass. 1936) 10-16; FTC Release, "Proposed Trade Practice Rules for the Automobile Industry," Feb. 19, 1940; Report of the Indiana Department of Financial Institutions on Indiana Consumer Finance Agencies (1935) 44; Report of the State Banking Commission and Interim Advisory Legislative Committee to Investigate Finance Companies (Wis. 1935) 42; Cavers, The Consumer's Stake in the Finance Company Code Controversy (1935) 2 LAW \& Contemp. Pros. 200-17; Legis., Protecting the Instalment Buyer (1935) 49 Harv. L. REv. 128; Hubachek, The Development of Regulatory Small Loan Laws, supra p. 108, at 129. 
Alone among the states, New York and New Jersey have laws which make special provision for the regulation of personal finance departments of banks. Elsewhere the legal status of these departments is obscure, although it is clear enough in many states to warrant the generalization that most of the banks are operating illegally. The banks in some states, attempting to avoid trouble under the usury laws, have resorted to various subterfuges, including discounts and hypotheticated accounts, which are satisfactory neither to borrowers nor to lenders." Supervision of pawnshops, for the most part, is for the purpose of recovering stolen goods, rather than for protecting legitimate borrowers of money.

In thirteen states, even the personal finance companies are not regulated under special statutes. As late as October, I940, the state examiner of North Dakota said, "The State has no statutes regulating the small loan business." At the same time, the state banking departments of Idaho, Kansas, Montana, Nevada, North Carolina, Oklahoma, South Carolina, South Dakota, and Wyoming, made similar statements. ${ }^{\circ}$ In these states the companies which make small consumer loans are subject to no special statutes. Mississippi approved an act on March 22, 1940, ${ }^{7}$ but it does not cover the small loan field, and the business is still uncontrolled. The State of Washington, which a year ago belonged wholly to this group, now partially regulates some of the business under a so-called "industrial" bank act, but there are still more illegal highrate lenders than licensed lenders; and it appears that these outlaw lenders, charging all the traffic will bear, collect from the borrowers about $\$ 2,000,000$ a year more than licensed lenders would be permitted to charge for the same loans-two million consumer dollars which are lost to legitimate business.

In Texas, the law is wholly ineffective; it does not enable any lender to operate legally, and it does not prevent any lender from operating illegally. In volume of loan shark business the state of Texas, as Rolf Nugent has pointed out in the first article of this symposium, ${ }^{8}$ has the sad distinction of standing first among the 48 states. In Dallas alone, since $193^{8}$ the center of a vigorous, anti-usury campaign, there are 53 loan shark offices. Throughout the state the illegal lenders, in spite of vigorous, incessant, well-planned harassment by such men as Al Heck, chairman of the Anti-Usury Committee of the San Antonio Bar Association, are reaping sufficient profits to pay for an increasing amount of direct mail and newspaper advertising in which they boldly state their illegal rates. Most of these rates, today as for a generation past, range between $10 \%$ and $20 \%$ a month. In the absence of a workable regulatory law, the efforts of the Attorney-General of Texas to curb the racket have been nullified by powerful, interstate chains of illegal lenders. The racket has become so widespread, he says, that it is a public menace. For understatement, this conclusion deserves a place of distinction. ${ }^{8}$

\footnotetext{
- Discussed in Consumer Loans by Commercial Banks (Pollak Foundation, 1940) Pamphlet No. 40.

- Letters to the Pollak Foundation. 'Miss. Laws 1940, c. 204.

- The latest study of the loan shark problem in Texas, published in November, r940, is A CENTURY of Usury in Texas by Edmunds Travis, published by the Cordova Press, Inc., Dallas, Texas. See pp. $55 \cdot 56$.
} 
A few other states have what appear to be small loan laws, but they are largely or wholly inoperative because the maximum legal rates are so low that lenders cannot obey the laws and stay in business. Virtually all the lending, therefore, is illegal and subject to no supervision or restrictions, with the exception of sporadic and largely ineffective raids on outlaw offices. This describes present conditions in five states: Alabama, Arkansas, Delaware, Georgia, and Tennessee. This is also the status of the District of Columbia. Over the District, the Congress of the United States has complete control, but has always refused to exercise it for the protection of hardpressed borrowers and of loan companies which would like to do business under a workable law.

Florida's law applies, with three exceptions, only to counties having a population

\section{SMALL LOAN LAWS OF THE UNITED STATES}

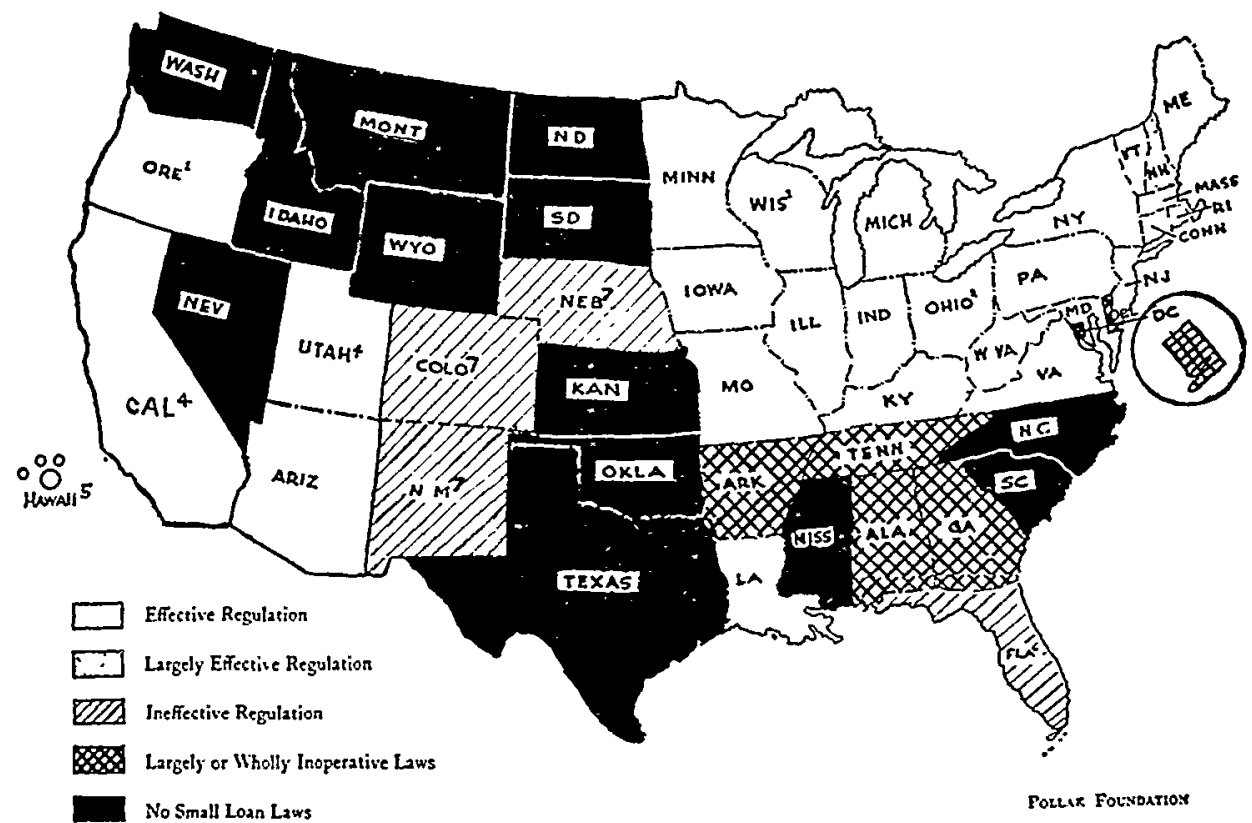

Nore: This map is adapted from Small Loan Laws of the United States, by LeBaron R. Foster (Pollak Foundation, 1939) Pamphlet No. 37. Different definitions of "effective" would require different classifications. Morcover, there are many borderline states, and various conditions as well as laws are constantly changing. I. Oregon's \$1 minimum charge encourages the making of \$1o loans at very high rates; and, as in Missouri, there is objectionable lending under the motor vehicle finance act. 2. Failure of the Ohio law to restrict licensees to small loans makes trouble. 3. Kentuckyt has failed to regulate loans on automobiles, but vigorous prosecutions in 1940 seem to promise improvements. 4. Laws adopted by California and Utah in 1939 place these states for the first time in the white area. 5. The Hawaiian Small Loan Law is sound, although very little business is done under it. 6. Florida's law covers only counies with large population and does not provide for regulation of salary buyers. 7. The laws of Nebraska, Colorado and New Mexico are defective in many ways: they bring in new capital, but they do not keep out very high-rate lenders. 8. New Hampshire's rate is marginal. There is relatively little lending, legal or illegal.

Substantially the same classification is given by Hubachek, supra pp. 123 et seq.

In some of the white states, borrowers have less protection than in others, on account of comparatively lax supervision of licensees. 


\section{Table I-Summary of Small Loan Laws 1}

(Abbreviations-USLL: Uniform Small Loan Law, approx.: approximates, dr.: draft. The Uniform Small Loan Law has been revised five times since first drafted in 1916. Since publishing the Sixth Draft in 1935, the Russell Sage Foundation has informally recommended certain improvements as to details and has the Seventh Draft in preparation. Compared to the refined and efficacious Sixth Draft, early drafts, though advanced for their time, were crude and inadequate.)

\section{Name of State (Effective Regulation) \\ Relation to USLL}

Arizona

California

Connecticut

Hawaii

Illinois

Indiana

Iowa

Kentucky

Louisiana

Maine

Maryland

Massachusetts

\section{Michigan}

Missouri

New Hampshire

New Jersey
New York
Ohio

Oregon

Pennsylvania

Rhode Island

Utah

Vermont

Virginia

West Virginia

Wisconsin
Early dr.; material variations

Two acts, taken together, approx. 6th dr.

Approx. 6th dr.; differs in form

Approx. 6th dr.

Approx. 6th dr.

Approx. 6th dr.; administrative rate control

Approx. 6th dr.; administrative rate control

Approx. 6th dr.; differs in form

Approx. $4^{\text {th }} \mathrm{dr}$.

Early dr.; later features

Early dr.; amendment approaches $4^{\text {th }} \mathrm{dr}$.

Prior to USLL; approx. carly drs. in substance; administrative rate control

Approx. 6th dr.

Approx. 6th dr.

Resembles $4^{\text {th }} \mathrm{dr}$.

Early dr.; amended to resemble $4^{\text {th }} \mathrm{dr}$.

Approx. 5th dr.

Approx. $5^{\text {th }} \mathrm{dr}$.

Prior to USLL; approx. early drs.; added features

Like $4^{\text {th }}$ dr.; material variations; auto loans separately regulated

Resembles 6th dr.; differs in form; lacks some features

Approx. 6th dr.

Early dr.; minor differences

Approx. 6th dr.

Early dr.; amended to resemble $4^{\text {th }} \mathrm{dr}$.

Like $4^{\text {th }}$ and 5 th drs.

Approx. 5th dr.; differs in form; administrative rate control

\section{Maximum Ratex}

$31 / 2 \%$

$2 \frac{1}{2}-2 \%$ at $\$ 100 ;$ flat $2 \%$ if security insured.

$3-2 \%$ at $\$ 100$

$3 \frac{1 / 2}{2}-2 \frac{1}{2} \%$ at $\$ 100$

$3-2 \frac{1}{2} \%$ at $\$ 150$

$3-1 \% \frac{1}{2} \%$ at $\$ 150$;

$50 \mathrm{c}$ fee on some loans

$3-2 \%$ at $\$ 150$

$31 / 2-21 / 2 \%$ at $\$ 150$

$31 / 2 \%$

$3-2 \frac{1}{2} \%$ at $\$ 150 ; 25 \mathrm{cmin}$. chg.

$31 / 2 \%$

$3-2 \frac{1}{2} \%$ at $\$ 150$ on unsecured

loans;

$3-2 \%$ at $\$ 150$ on chattels and endorsed notes; other rates

$3-2 \frac{1}{2} \%$ at $\$ 100$

$3 \%$

$3-2 \frac{1}{2} \%$ at $\$ 100^{\circ}$

$2 \%$; fees, in advance, of $\$ 1$ on loans up to $\$ 50, \$ 2$ on larger loans up to $\$ 300^{3}$

$2 \frac{1}{2} \%$

$3-2 \frac{1}{2} \%$ at $\$ 150$

$3 \%$;

$\$$ I fee on $\$ 50$ or less

$3 \%$;

$\$ 1$ min. chg.

$3-2 \%$ at $\$ 150$;

$6 \%$ per an. after 18 mos.

$3 \%$

$3 \%$

$21 / 2-21 / 4 \%$ at $\$ 125$

$31 / 2 \%$

$3 \frac{1}{2}-2 \frac{1}{2} \%$ at $\$ 150$

$21 / 2-2-1 \%$ at $\$ 100$ and $\$ 200$

${ }^{2}$ Particulars are taken from Hubachek, Annotatjons on Small Loan Laws (1938), Robinson and Nugent, Regulation of the Small LOAN Business (1935), and other sources. These tables reproduced from Pollak Foundation Pamphlet No. 37, Small Loan Laws of the United States (1940).

Canada enacted a small loan law, effective January 1, 1940, which provides a maximum charge of $2 \%$ per month, computed on unpaid balances. This law applies in all provinces.

2 Rate per month on unpaid principal balances, unless otherwise indicated. Where more than one rate is given, the rate is a graduated rate; that is, the first rate is charged on a part of the balance up to a certain amount, and the second rate on the remainder. Thus, in Connecticut, the maximum charge for a month during which the balance is $\$ 140$ is $3 \%$ of $\$ 100$ plus $2 \%$ of $\$ 40$, or $\$ 3.80$.

${ }^{3}$ Step rate, i.e., maximum on loan over $\$ 100$ is $21 / 2 \%$ a month throughout its life, and on loan of $\$ 100$ or less is $3 \%$ throughout. Above details and classification reflect amendments to the Missouri law enacted in.1939. Because of the limited area, population and market of New Hampshire, and because legal small loan offices are available in-three adjacent states, valid generalization as to adequate rates cannot be deduced from the experience of New Hampshire. 


\section{Table I-Continued}

Name of State

Relation to USLL

Maximum Rate

(Inefective Regulation)

Colorado Differs greatly; permits fees and extra charges

Florida

Approx. 4th dr.; material variations

other chgs."

$3 \frac{1}{2} \%$

Nebraska Differs greatly; examination fee may be deducted $10 \%$ a year; fee of 1110 of loan; $50 c$ in advance, but other charges may not. No size exam. fee on loans of $\$ 50$ or less ${ }^{8}$ limit on loans

New Mexico Differs greatly; permits fees and extra charges

(Largely or Wholly Inoperative Laws)

$10 \%$ a year; fee of $1 / 10$ of loan; other chgs. ${ }^{\circ}$

Alabama

Resembles $4^{\text {th }} \mathrm{dr}$.

Arkansas Many features of USLL; no rate provision

Dist. of Col.

Inadequate law; $\$ 500$ license fee

Delaware

Inadequate law; supervision insufficient; suited to commercial and industrial banks

Georgia Early dr. of USLL

$8 \%$ a year

$10 \%$ per an. (usury law)

$1 \%$ a month

Mississippi

Crude and confused; excessive fees; those charg ing more than $20 \%$ per an. (a violation of law) to pay privilege tax of $\$ 2000$; ineffective supervision

Tennessee $\quad$ Resembles $4^{\text {th }} \mathrm{dr}$.; material variations

$8 \%$ discount, including fee computed on original amount of loan $1 \mathrm{1} / 2 \%$ a month

$10 \%$ per an.; fees

$6 \%$ a year; fee of not exceeding $1 \%$ a month

$10 \%$ per an. (usury law)

Very crude law; no size limit; no supervision

Texas
(No special Small

Loan Laws)

Idaho, Kansas, Montana, Nevada, North Carolina, North Dakota,

Oklahoma, South Carolina, South Dakota, Washington, Wyoming ${ }^{7}$

- $10 \%$ per annum, plus fee of $1 / 10$ of amount actually loaned chargeable not more than twice in any calendar year, plus insurance charge, on auto loans, of $\$ 5$ for each $\$ 100$ or fraction thereof loaned. Special schedule of charges for loans of $\$ 50$ or less.

${ }^{5}$ 10\% per annum, plus brokerage fee of tho of amount actually loaned, plus examination fee of $50 \mathrm{c}$ on loans not exceeding $\$ 50$. The fees must be prorated on loans maturing in less than six months. The brokerage fee may be repeated after six months if loan is renewed, extended or transferred for an additional six months or more.

- Footnote 4 applies, except that on auto loans lender may charge, for his own single interest protection, $50 \mathrm{c}$ for each $\$$ ro of the amount loaned, and in addition may collect for other insurance of the security.

'Wyoming limits the contract rate of interest to $10 \%$, and in addition makes it a misdemeanor to charge more than $25 \%$ per annum on sums less than $\$ 200$.

\section{Table II-Summary of Maximum Rates \\ in States with Operative Small Loan Laws}

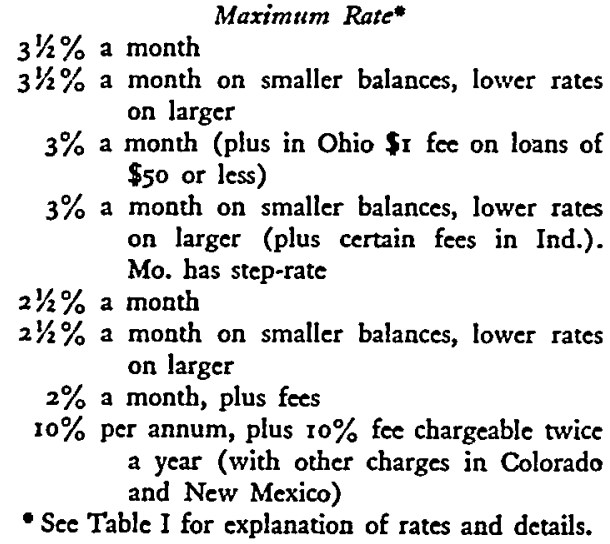

3 (Hawaii, Ky, W. Va)

5 (Minn., Ohio, Ore., R. I., Utah)

Io (Conn., III., Ind., Ia., Mass., Me., Mich., Mo., N. Y., Pa.)

1 (N. J.)

3 (Calif., Vt., Wis.)

I (N. H.)

3 (Colo., Neb., N. Mex.) 
of 40,000 or more. Worse still, the omission of Section 16 of the Uniform Small Loan Law enables salary buyers of the worst type to operate freely. ${ }^{10}$

In three other states-Colorado, Nebraska, and New Mexico-the regulatory laws differ in essentials from the small loan laws which have proved reasonably effective in 25 states. In Colorado and New Mexico, loans of $\$ 50$ or less may be made legally at extremely high rates.

The 25 states which have done most to bring the business under control-the white ones on the map-are Arizona, California, Connecticut, Illinois, Indiana, Iowa, Kentucky, Maine, Maryland, Massachusetts, Michigan, Minnesota, Missouri, New Hampshire, New Jersey, New York, Ohio, Oregon, Pennsylvania, Rhode Island, Utah, Vermont, Virginia, West Virginia, and Wisconsin. The right of Kentucky to a place in this list may be questioned on account of the flourishing high-rate automobile loan business which still goes on; and in Oregon, very high-rate offices, making nothing but very small loans, can and do operate legally, because the law permits a minimum charge of one dollar' on any loan.

This classification of the states is shown in the map, page 159 .

\section{Results of Regulation IN New York State}

Of the 25 states which have workable small loan laws, no two have quite the same degree of success in regulating the business. New York State, however, is perhaps as good an example as any other. This state has experimented with various types of regulation since 1895 , and since 1932 has had extensive experience under the present Licensed Lenders Act. ${ }^{11}$ The principal features of this Act, moreover, are features of the laws in those states which have done most toward providing, under rigid control, adequate small loan services. An additional reason for selecting this state as an example is that, among the 269 licensed lenders who made reports covering operations for the year $193^{8}$, there were lenders with very small capital and lenders with very large capital, and lenders in small and in large towns, and among them were single offices, local chains, minor national chains and major national chains. A final and conclusive reason for selecting New York as an example at this time is the fact that, in 1940, the Superintendent of Banks made a special extensive study of the earnings and expenses of licensed lenders in that state, a study prepared with the valuable assistance of Dr. Rolf Nugent, Director of the Department of Consumer Credit Studies, of the Russell Sage Foundation. ${ }^{12}$

\section{Principal Features of the New York State Licensed Lenders Act}

The Act applies to all persons engaged in lending sums up to $\$ 300$ at a rate of charge higher than $6 \%$ a year, except pawnbrokers and agencies chartered under

\footnotetext{
${ }^{10}$ See Kizgore, $240 \%$ Loan Shark Racket (1940) and Hubachek, supta p. I24.

${ }^{11}$ N. Y. Consol. Laws (Cahill, Supp. I93I-1935) c. 3, art. 9, \$\$340.365.

${ }^{12}$ White, Special Report of the Superintendent of Banks of the State of New York Relative to Licensed Lenders (1940).
} 
certain other specified acts. It requires that all such lenders be bonded, and be licensed and supervised by the State Banking Department. It regulates their practices with respect to advertising and solicitation, computation of charges, and compiling of records. The charges permitted are $3 \%$ a month on that part of any loan not in excess of $\$ 150$, and $2 \frac{1}{2} \%$ a month on the rest. The Banking Department is required to examine the books and records of each licensee, periodically, and to prepare a summary of annual reports. The Superintendent of Banks may, at his discretion, issue, suspend, or revoke licenses and issue regulations in furtherance of the purposes of the act. Violators, licensed and unlicensed, are subject to both civil and criminal penalties.

This Act differs from those which have to do with other money-lending agencies in the state in two respects. First, the Act not only regulates licensed lenders, but applies to all lenders, in sums of $\$ 300$ or less, not specifically exempted. That is one reason why, in New York State as well as in other states, the attacks of illegal lenders are always directed toward the Uniform Small Loan Law. This is the law which hampers them: it supplements the usury laws. A second significant feature of the Act is that under it the responsibility of the banking department is solely the protection of borrowers.

Under this Act the licensed lender is required to state his charges in one clear, inclusive figure, as a per cent per month, on the actual, unpaid balance. The charges of credit unions, personal loan departments of banks, and industrial banks may be increased as a result of fines for delinquency, whereas the Licensed Lenders Act prohibits additional charges for this or for any other reason. Furthermore, other agencies may, to some extent, pass on to individual borrowers the costs of collecting defaulted loans, whereas licensed lenders may not do so.

\section{Reported Earnings of Licensed Lenders in New York State}

After omitting, for stated reasons, some of the reports of licensed lenders, and after making various changes in the reports of other lenders, with the stated object of bringing the figures more closely in accord with true net earnings, the Superintendent of Banks found that, for the year 1938 , the 200 licensees included in his report had estimated employed assets of about $\$ 52,000,000$, expenses of about $\$ 8,500,000$, and net earnings of $11.25 \%$.

The used and useful assets of all lenders, however, as reported from $193^{2}$ to $193^{8}$, inclusive, ranged all the way from about $\$ 10,000,000$ the first year to about $\$ 64,000,000$ the last year, and the rate of net earnings ranged from $8.19 \%$ the first year to $8.88 \%$ the last year. In the poorest year, I933, the rate was $6.62 \%$, and in the best year, I937, the rate was $9.93 \%$.

According to the adjusted figures, the net earnings in 1938 were: for single offices, II.28\%; for local chains, $9.70 \%$; for minor national chains, $10.36 \%$; and for major national chains, II.98\%. The lowest rate of net return, $4.75 \%$, was for loans of less than $\$ 50$, and the highest rate, $11.87 \%$, was for loans of $\$ 150$ to $\$ 175$. Places of 30,000 
to 50,000 population had the highest rate of earnings, namely $15.07 \%$, and New York City, with $10.07 \%$, the lowest. These rates, however, based on the adjusted figures, are not comparable with the rates usually reported for other industries, for such rates are not based on similar adjustments of corporation reports.

\section{Reported Expenses of Licensed Lenders in New York State}

For all types of lenders-single units, local chains, minor national chains and major national chains-by far the largest item of expense is salaries. This item in 1938 ranged from $4.8 \%$ of average employed assets, for major national chains, to $7.4 \%$ for single units. Advertising expenses ranged from $1.17 \%$ for single units to $2.09 \%$ for local chains. An analysis of total expenses is shown in the following table:

\begin{tabular}{|c|c|c|}
\hline & Amount & $\begin{array}{l}\text { employed } \\
\text { assets }\end{array}$ \\
\hline Advertising & 930,394 & 1.7781 \\
\hline Auditing $\ldots \ldots \ldots \ldots \ldots \ldots \ldots$ & 81,963 & .1566 \\
\hline Bad debts or reserve for bad debts........ & 847,440 & $1.6 \mathrm{rg} 6$ \\
\hline Depreciation of furniture and equipment $\ldots \ldots \ldots \ldots \ldots$ & 80,109 & .1531 \\
\hline Expenses, sundry $\ldots \ldots \ldots \ldots \ldots \ldots \ldots \ldots \ldots \ldots \ldots$ & 227,724 & .4352 \\
\hline Insurance and fidelity bonds $\ldots \ldots \ldots \ldots \ldots \ldots \ldots$ & 116,828 & .2232 \\
\hline Legal fees and disbursements $\ldots \ldots \ldots \ldots \ldots \ldots \ldots \ldots$ & 177,909 & .3400 \\
\hline Postage and express $\ldots \ldots \ldots \ldots \ldots \ldots \ldots \ldots$ & 115,707 & .2212 \\
\hline Printing, stationery and supplies ....... & 156,667 & .2995 \\
\hline Rent $\ldots \ldots \ldots \ldots \ldots \ldots \ldots \ldots \ldots$ & 539,077 & 1.0303 \\
\hline 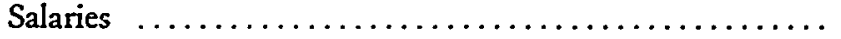 & $2,868,862$ & 5.4829 \\
\hline Supervision and administration $\ldots \ldots \ldots \ldots \ldots \ldots \ldots$ & 365,733 & .6990 \\
\hline Licenses and license taxes $\ldots \ldots \ldots \ldots$ & 22,356 & .0428 \\
\hline State and local taxes .... & 340,217 & .6503 \\
\hline Federal taxes $\ldots \ldots \ldots$. & 881,052 & 1.6839 \\
\hline Telephone and telegraph $\ldots \ldots \ldots \ldots \ldots \ldots \ldots \ldots$ & 272,916 & .5216 \\
\hline 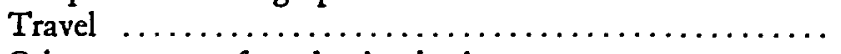 & 303,319 & .5797 \\
\hline Other expenses of conducting business $\ldots \ldots \ldots \ldots \ldots \ldots$ & 220,633 & .4217 \\
\hline Total & 548,906 & $16.33^{8} 7$ \\
\hline
\end{tabular}

\section{Exactly What Happens Under Rigid Regulation?}

Exactly what happens when a company, with adequate capital and experience, operates widely but only in states which rigidly regulate the business? The records of Household Finance Corporation of Chicago seem to answer that question as well as any other. Up-to-date figures as accurate and as comprehensive for all the licensed offices in the entire country, of which there are 4,558 , are not available. Even if they were, averages of such diverse data would not be as meaningful for most purposes as records of a single, well-established corporation, which maintains offices in most of the states which have brought the business under reasonably stringent control. ${ }^{13}$

\footnotetext{
${ }^{13}$ Data concerning incomes and occupations of borrowers, reasons for borrowing and size of loans,
} 
Here, taken from publications of this corporation, are the chief items, all for 1939:

Household Finance Corporation and Substdiaries

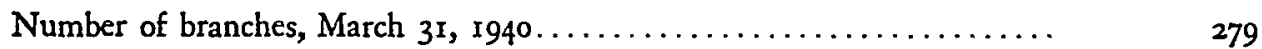

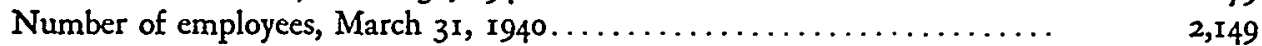

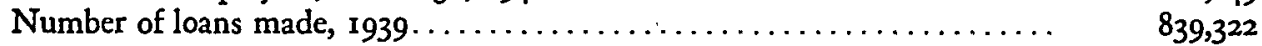

Amount of loans made, r $939 \ldots \ldots \ldots \ldots \ldots \ldots \ldots \ldots \ldots \ldots \ldots \ldots \ldots \ldots \ldots \ldots \ldots \ldots, 494,413$

Capitalization, March 31, 1940:

$5 \%$ Preferred Stock (Listed on N. Y. Stock Exchange) . . . . . . .

Common Stock (Listed on N. Y. Stock Exchange) ............. $\ldots$ 18,432,650

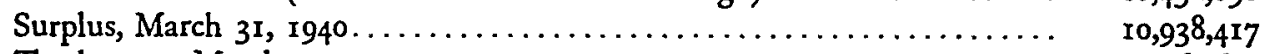

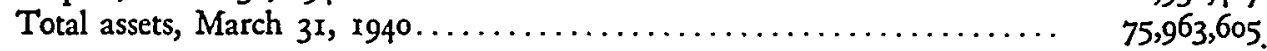

Annual Income and Expense of the Average Office, 1939

Gross Income

Small loan charges collected.

\section{Expenses}

Salaries

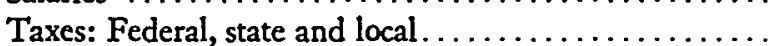

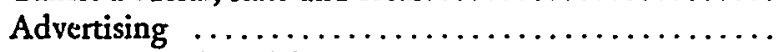

Provision for bad debts......................

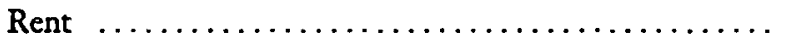

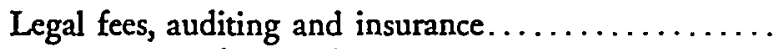

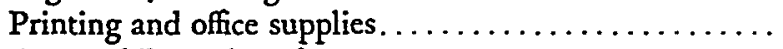

Automobile and carfare.

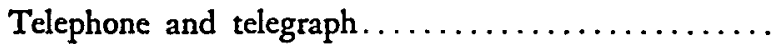

Travel expenses ...........................

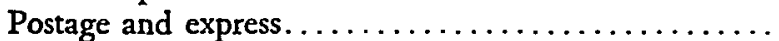

Consumer education literature

Depreciation, maintenance, and rental of machines and equipment.

Credit exchange and association dues.

Miscellaneous

Total Expenses.

Net earnings (Before interest charges)

\begin{tabular}{rc}
$\begin{array}{c}\text { Average } \\
\text { amount } \\
\text { per office }\end{array}$ & $\begin{array}{c}\text { Monthly } \% \text { of } \\
\text { average amount } \\
\text { of loans out- } \\
\text { standing }\end{array}$ \\
$\$ 73,128$ & 2.46 \\
16,091 & .54 \\
8,174 & .28 \\
7,633 & .26 \\
4,510 & .15 \\
2,981 & .10 \\
1,832 & .06 \\
1,046 & .04 \\
1,008 & .03 \\
953 & .03 \\
683 & .02 \\
574 & .02 \\
524 & .02 \\
486 & .02 \\
421 & .01 \\
716 & .02 \\
\hline$\$ 47,632$ & .60 \\
\hline 496 & .60
\end{tabular}

(Equivalent to return of $9.39 \%$ a year on employed assets of $\$ 271,462$.)

\section{Why Do They Borrow?}

Principal Use of Money

Medical, dental, and hospital bills.

To consolidate overdue bills.

Clothing

\section{Number of \\ loans}

r30,707

88,901

88,577
Per cent of total

I5. 88

10.59

10.56

covering other companies, for earlier years, are given in Young and Associates, Personat. Finance ConsPanies and Thetr Credit Practices (Nat'l Bur. Econ. Res., 1940) c. 2. Data in this volume furnished by American Investment Company, of Illinois, and Beneficial Industrial Loan Corporation provide a rough means of estimating to what extent the data given for operations of Household Finance Corporation are typical of the business of the largest corporations. Sec, also, Neifeld, Personal Finance Comes of Age (1939) c. 15. The latest figures in these two volumes, however, are for 1937. 
Miscellaneous

60,934

Travel expense

55,835

Business needs

53,475

Home furnishings $\ldots \ldots \ldots \ldots \ldots \ldots \ldots \ldots \ldots \ldots \ldots, \quad 4,4,270$

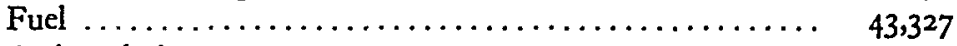

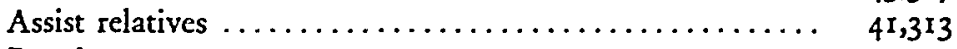

Repairs ........................... 40,347

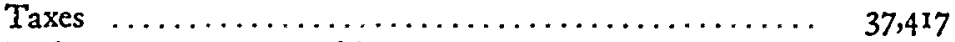

Real estate mortgage and interest .............. 30,745

7.26

6.65

6.37

5.75

5.16

4.92

4.81

4.46

$30,745 \quad 3.66$

Automobile expense

$29,780 \quad 3.55$

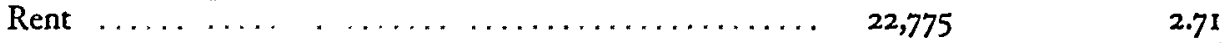

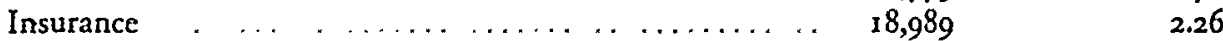

Moving expense $\quad \ldots \ldots \ldots \ldots \ldots \ldots \ldots \ldots \ldots \ldots 1,16,550 \quad 1.97$

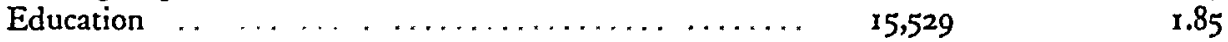

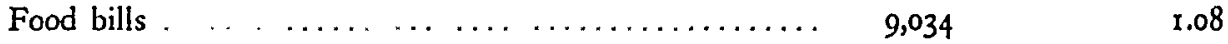

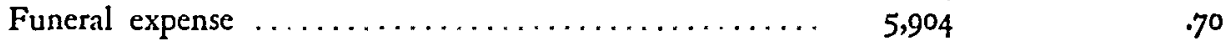

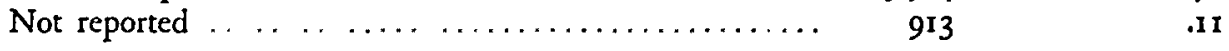

Total

839,322

100.00

In this table, all loans are classified under the heading describing the use to which the larger part of the loan was applied. Where several bills were paid and no major purpose appeared, the loan is classified under the heading, "To consolidate overdue bills."

How Much Do the Borrowers Earn Per Month?

\begin{tabular}{|c|c|c|}
\hline Income per month & Number of loans & Per cent of total \\
\hline Over $\$ 250 \ldots \ldots \ldots$ & . 96,811 & 11.53 \\
\hline$\$ 201-\$ 250 \ldots \ldots$ & 99,615 & 11.87 \\
\hline 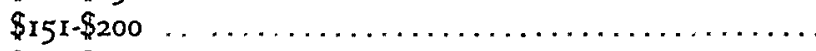 & 224,499 & 26.75 \\
\hline 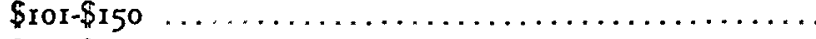 & 293,107 & 34.92 \\
\hline 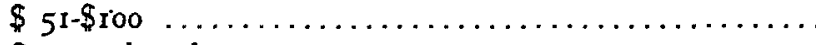 & 119,853 & 14.28 \\
\hline 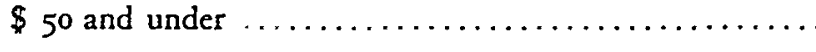 & 5,437 & .65 \\
\hline Total & 839,322 & 100.00 \\
\hline
\end{tabular}

What Do They Do for a Living?

Manufacturing

Percent

of rotal

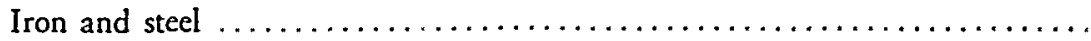

$5 \cdot 76$

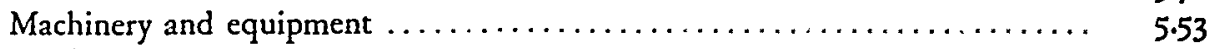

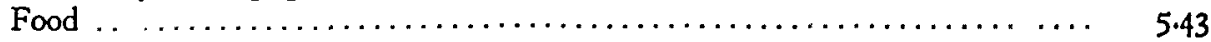

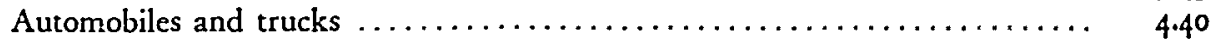

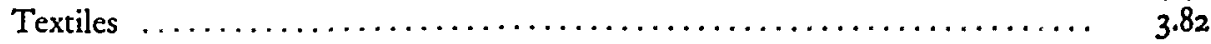

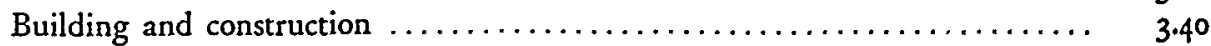

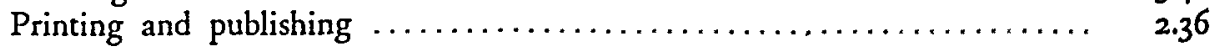

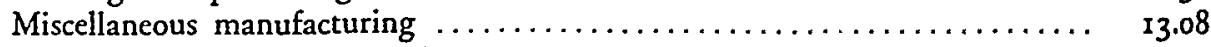

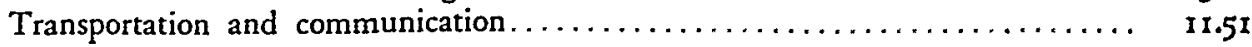

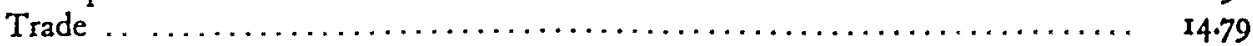

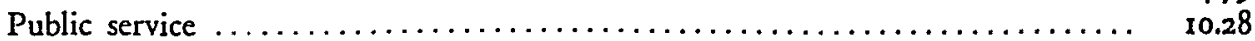

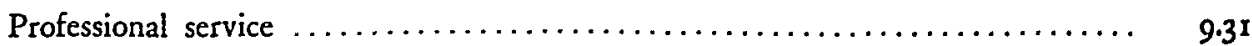

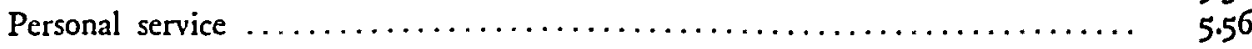




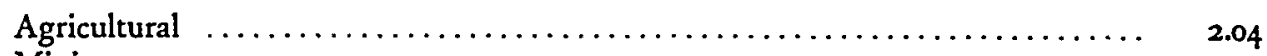

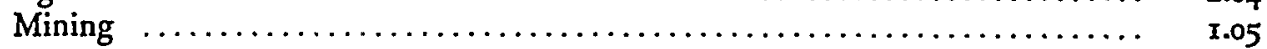

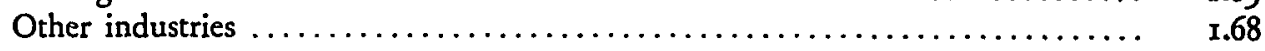

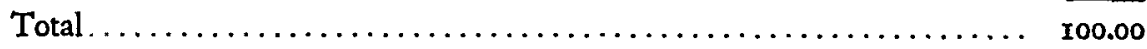

The Average Finance Office in 1939

Average employed assets 14

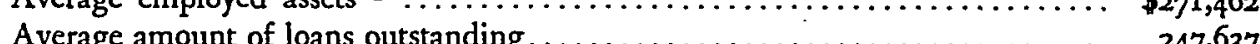

Arion

Ratio of employed assets to amount of loans outstanding................., ${ }_{110 \%}$

Average number of loans outstanding $\ldots \ldots \ldots \ldots \ldots \ldots \ldots \ldots \ldots \ldots \ldots, \quad 2013$

Average size of loan balances outstanding $\ldots \ldots \ldots \ldots \ldots \ldots \ldots \ldots \ldots \ldots, \quad \$ 123.01$

Average rate collected per month as $\%$ of loans outstanding............... $\quad 2.46 \%$

Average rate collected per month as $\%$ of employed assets................ $\quad 2.24 \%$

The average size of loan balances is somewhat higher, and the average rate collected somewhat lower, than for licensees as a whole.

Sizes AND Life OF LOANS IN 1939

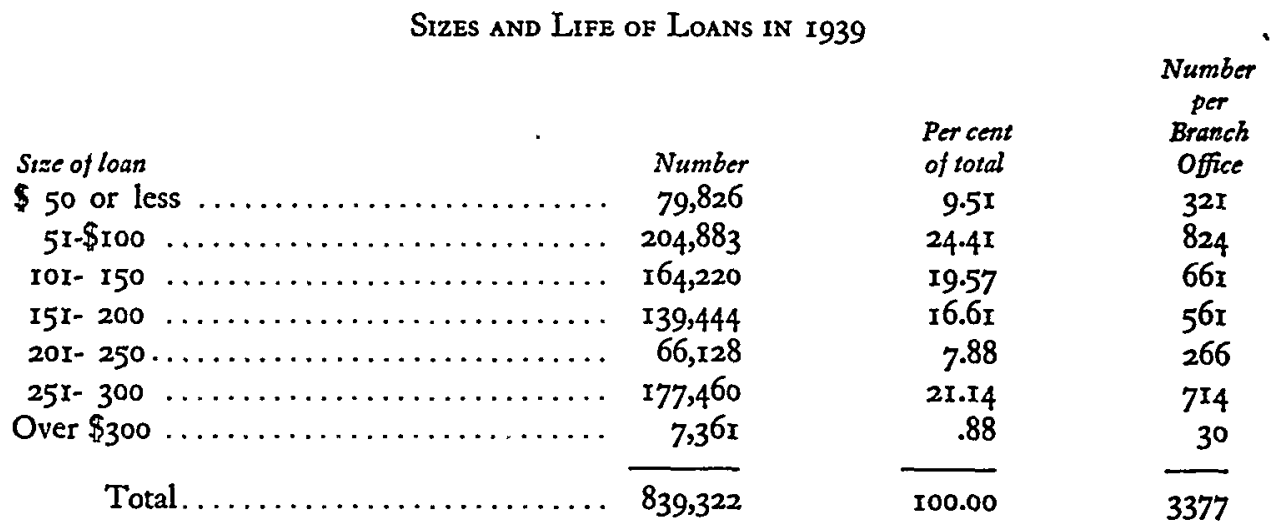

Average life of loans repaid without renewal or borrowing of additional money

Average life of indebtedness of all borrowers, including those who

renewed or obtained additional money.

I5.70 months 26.57 months

What Per Cent of Income Is Required to Repay Average Loans?

Based on actual contract terms of loans currently made in March, I940, 7.5I per cent of the average monthly income of the borrowers was required to pay the average loan. The average loan made was the same as the average monthly income, namely $\$ 165$. The average monthly payment required, including principal and interest, was \$12.37. Thus, the average borrower had 92.49 per cent of his income available for purposes other than payments on his loan. ${ }^{15}$

\footnotetext{
If Includes necessary non-earning assets such as cash on hand, investment in office equipment, prepaid expenses, etc., in addition to funds actually out on loan. In 1939 employed assets averaged \$1.1o for cvery Si of loan balance outstanding.

${ }^{25}$ For per cent of income required to repay loans made by the Detroit offices of the same Corporation, for the first quarter of 1936 , classified by sizes of loans and by incomes of borrowers, see Young AND Associates, op. cit. supra note 13 , at 48 .
} 


\section{What Security Is Taken for Loans of Personal Finance Companies?}

The majority of loans of most of the licensed personal finance companies are character loans. There is no adequate tangible security. To be sure, it has long been the custom of licensed lenders to make loans on chattel mortgages on household goods, but such mortgages are of scarcely any worth as tangible security. They have been taken mainly for their moral effect on the borrower. Even when chattel mortgages are taken, in not one case out of a thousand is the furniture actually seized. To an increasing extent, loans are made on unsecured notes. In Ir important states in 1937, the loans made by personal finance companies, secured by endorsed and comaker notes and wage assignments, all three classes combined, averaged less than $11 \%$ of the business. ${ }^{16}$

\section{What Is the Rate of Earnings of Personal Finance Companies?}

In 1938 the net earnings ratios in 18 of the best-regulated states were as shown in the following table. These ratios are taken from the annual reports of the state supervisory departments. In each case the figure is the annual net earnings on employed assets, before deducting interest paid on borrowed capital.

\begin{tabular}{|c|c|}
\hline Connecticut $\ldots \ldots \ldots \ldots \ldots$ & $* 6.92 \%$ \\
\hline Illinois $\ldots$. & 8.86 \\
\hline Indiana & 8.94 \\
\hline$\ldots \ldots \ldots \ldots \ldots$ & 9.75 \\
\hline Kentucky $\ldots \ldots \ldots \ldots \ldots$ & 7.94 \\
\hline Maryland $\ldots \ldots \ldots \ldots \ldots$ & $7 \cdot 77$ \\
\hline Massachusetts $\ldots \ldots \ldots \ldots$ & * 7.30 \\
\hline Michigan $\ldots \ldots \ldots \ldots \ldots \ldots$ & 8.85 \\
\hline Missouri $\ldots \ldots \ldots \ldots \ldots \ldots$ & $6.8 \mathrm{r}$ \\
\hline
\end{tabular}

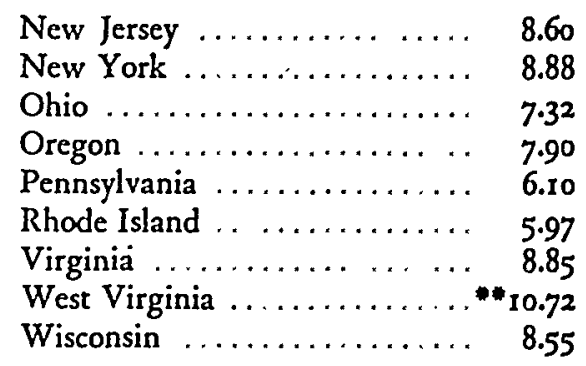

- Year ended September 30, 1938.

- Year ended June 30, 1938.

The net income of personal finance companies, $1929-36$, as a per cent of average employed assets, varied from $11.7 \%$ in 1929 to $9.0 \%$ in 1936 . The lowest net income, $6.7 \%$, was in the year $1933 . .^{17}$

\section{What Maximum Rates Resuit in the Most Effective Rzgulation ? $^{18}$}

The costs of providing small loans rise rapidly as such services are rendered to a larger proportion of the population; and a considerably larger proportion is being served now than was served five years ago. Moreover, the smaller the loan and the greater the risk, the higher must be the charge per dollar of credit granted. Commercial bank rates for business loans cover the costs only on preferred risks. Next in the scale of risks are the loans of industrial banks, Morris Plan banks and personal loan departments of commercial banks, which are made on the security of notes en-

\footnotetext{
${ }^{30}$ See table in Pollak Foundation Pamphlet No. 40, supra note 5, p. 18.

17 Young AND Associates, op. cit. supra note 13, at 113 . Data for 1929-33 are based on Roninson AND Nugent, Regulation of the Smali Lonn Business (Russell Sage Foundation, 1935). Sec also Nugent, Eamings of Small Loan Licensees, 1929-33 (1935) 13 HARv. Bus. Rev. 249. See also, NeIfELD, op. cit. supra note 13 , c. $3 \mathrm{~T}$.

${ }^{28}$ This question is fully and soundly discussed in RoBINson AND NugeNT, op. cit. supra note 17, c. 12.
} 
dorsed by responsible co-makers. Also in the preferred class as to risk are pledge loans of remedial loan associations and some loans of credit unions. All such loans, serviceable as they are, are available only to the small proportion of men and women who can meet the requirements. Wherever the laws do not permit licensed companies to charge sufficiently high rates on unsecured loans, the loan sharks step in and provide such loans in total disregard of the law.

The ideal from the standpoint of social welfare is complete loan service, either on a business basis or on a credit union basis, for every self-supporting family that -needs it; and those who seek the smallest loans-the loans which cost the lender the most per dollar-often are in the direst need of help.

Where shall the line be drawn? The costs of making a loan of $\$ 5$ may justify a rate of $10 \%$ a month or higher; but is it socially beneficial to legalize loans at that rate? Each legislature must decide, bearing in mind the fact that rates determine the extent to which credit is granted. Too high a rate permits and encourages overlending. Too low a rate denies help to many who would be benefited by it. Several wellregulated states experimented with maximum rates which proved too low: rates of $2 \%$ per month and even lower. Nearly all these states subsequently raised their rates to workable levels and are now among the white states on our map.

The most that can be said here is that rates should be high enough to attract a sufficient number of licensed offices with sufficient capital to keep out the loan sharks. What rates are likely to accomplish this purpose should be determined on the basis of thorough, impartial studies in each state and records which the licensees should be required to file with the State Banking Department; and the whole matter should be reviewed, from time to time, to determine whether changed conditions warrant changes in the maximum permitted rates.

\section{How Effective Is Competition Under State Regulation?}

Attempts to bring the small loan business under state control by means of the Uniform Small Loan Law have met vigorous opposition from some local companies, on the ground that the law would attract national companies with large capital, and that these companies would put the local lenders out of business. It has been said, further, that these well-financed companies would raise the cost of credit to consumers because, following well-known examples, they would first reduce rates to unprofitable levels, in order to kill off competition, and then, when they had the field to themselves, they would raise the rates. In several states, Alabama for example, these arguments are used today in successful attempts to prevent passage of regulatory acts.

In this connection, the experience of Massachusetts, one of the states which has had long experience with rigid regulation, is illuminating. In October, 1940, operating under the Small Loan Law, were 85 local, independent companies and 3 national companies; and these independent companies made loans in twelve months of about $\$ 12,000,000$. Evidently, competition from outside the state did not prevent the homegrown plants from taking root. In the rest of the country as well the small companies have held their own. This is evident from the fact that, in 1936, there were 1066 
offices belonging to 39 companies, including all of those which had five or more memberships in the American Association of Personal Finance Companies; yet there were about twice as many offices belonging to other companies. ${ }^{10}$

The objection that large national companies increase the costs of loans to consumers is not supported by the facts. In Massachusetts, for example, the maximum rate which was first permitted under the law was $3 \%$ per month, but reductions have been made until now the permitted rate on unsecured loan balances in excess of $\$ 150$ is $21 / 2 \%$ per month, and the rates on secured notes are $2 \%$ for some and $1 \%$ for others. The actual average charges are lower still, partly because a large number of offices which are owned by outside capital, and directed from outside the state, do not charge rates as high as the law permits.

The small loan business, however, is a case of imperfect competition. Not all borrowers take advantage of the lowest rate available to them, because they buy much more than the use of money. In choosing a lender, they are influenced by custom, friendship, convenience of location, privacy, speed, advice of friends, advertising, expectation of leniency when and if needed, and other non-price factors. ${ }^{20}$

\section{To What Extent Are Commercial Banks Entering the Field?}

The recent rapid growth of personal finance departments of commercial banks (see Chart I) suggests the question to what extent the banks will take over the business of personal finance companies. It appears that commercial banks now have and will continue to have a clientele all their own. This is apparent from the size of their loans, the distribution of their borrowers among vocations and among income classes, from other factors in the costs and risks of doing their present part of the consumer business, and from the comparatively low rates which, in consequence, the banks are able to offer to the applicants whose business they accept.

Commercial banks deal with borrowers in relatively high income groups, chiefly in the $\$ 2,000-\$ 2,500$ group, as compared with the $\$ 1,500-\$ 2,000$ group which shows the highest frequency for personal finance company borrowers. ${ }^{21}$ The records of the three largest companies-American Investment Company, Beneficial Industrial Loan Corporation and Household Finance Corporation-which make about half the dollar volume of loans made by licensed companies, seem to show that three fourths of all loans made by these companies are to borrowers in the $\$ 1,000-\$ 2,500$ income class.

To a large extent, also, commercial banks and personal finance companies serve different occupational groups. The occupational distribution of borrowers of personal finance companies is about the same as that of the entire working population: in both cases $52 \%$ are wage earners. Furthermore, clerical workers are about $25 \%$ of the population and about $25 \%$ of personal finance company borrowers. Only a small

\footnotetext{
${ }^{10}$ NeIFELD, op. cit. SUPra note I3, c. I2.

${ }^{20}$ See Yntema, The Market for Consumer Credit: a Case in Imperfect Competition (March, 1938) 196 ANNALS 79.

21 See, Chupman and Associates, Commercial Banks and Consumer Instazment Credit (Nat'l Bur. Ecan. Res., 1940) 64-68.
} 
proportion of low income farnilies are in the occupational groups which are served by the banks. ${ }^{22}$

There are also important differences in the sizes of loans. The personal finance companies are the chief enemies of high-rate illegal lenders partly because they make more loans of less than \$100 than any other legal agency. Most of the borrowers of such small sums give no promise of profitable business to the banks, even though a majority of the banks make charges which, figured on declining balances-that is to say, on the money of which the borrowers actually have the use-amount to from $12 \%$ to $17 \%$ per year. The banks cannot, at these rates, cover expenses on the class of small loans which is a large part of the business of personal finance companies.

Recently, commercial banks and other consumer credit agencies, notably industrial banks and personal finance companies, have stiffened competition with sales finance companies. These agencies, reaching the instalment buyer directly and providing him with cash, have left the dealer completely out in an increasing volume of credit transactions. ${ }^{23}$

\section{How Successful Is the Best Regulation?}

In some of the 25 states which have satisfactory laws, enforcement is more effective than in others, and in all these states the degree of success varies from year to year. The small loan law does not enforce itself. From a majority of these 25 states, however, the high-rate lenders have all but vanished. "By this statute," says the Chief of the Consumer Credit Division of Pennsylvania, "the so-called 'loan sharks' have been eliminated." The Supervisor of Loan Agencies of Massachusetts makes the same report: "We have found no difficulty," he says, "in keeping licensees to a full observance of the law and the rules and regulations promulgated thereunder." The head of the Division of Small Loans in Indiana says: "The loan sharks have been eliminated; the licensees observe the law; they serve the small borrowers adequately; and social agencies approve the legislation." The Commissioner of Finance of Missouri, in a report to the Governor in 1940, says: "The licensees as a whole manifest a splendid spirit of cooperation with this Department in the observance and administration of the law." A Citizens' Committee in Wisconsin, reporting outcome of a state-wide poll of customers of small loan companies, said that $93.2 \%$ of the 13.487 borrowers who voted were against the proposed repeal of the small loan act. The Department of Banking of Iowa says: "Iowa has had a small loan law since I921, and during that period of years we have not had any trouble.with the loan sharks. ... We have not had a single complaint registered by a borrower in more than two years." By way of contrast, we may note, in passing, the attitude of borrowers in a state which has no regulation. In Texas, in ten weeks of 1938, an anti-usury committee received 2554 complaints from borrowers in a single city, the average rate charged in the first rooo cases having been $271 \%{ }^{24}$

\footnotetext{
${ }^{22}$ See charts of income groups in Consumer Incomes in the United States (Nat'l Resources Committee, 1938).

${ }^{23}$ Plummer and Young, op. cit. supra note 4 , at 285-288.

34 The Dallas Loan Shark Fight (Better Business Bureau of Dallas, 1939) 15-17. See, also, Foster, Loan Sharks and Their Victims, Pamphlet No. 39 (Public Affairs Committee, 1940) 7. Quotations in this paragraph, not identified, are from letters to the Pollak Foundation, October, 1940.
} 
However, even in states which have the best of laws, complaints are heard from time to time. As illegal lenders are driven out of one state after another, they seek communities in which they can devise new methods of evading the law, or at least of avoiding detection. In New York State recently, Prosecuting Attorney Thomas Dewey found it necessary to take vigorous action against a number of bold and powerful outlaw lenders. The most important point to notice, in this connection, is that even such an able and determined prosecutor could have accomplished little had not most of the small loan business in the state been successfully regulated, and had there not been a law covering all lenders of small sums, not otherwise regulated. ${ }^{25}$

The Future of Regulation

For the immediate future the chief objective in regulating the personal finance business should be to bring the backward states up to the standards of the leaders. Between the worst and the best, the range is now almost as wide as between black and white: the shades on the map represent the varied conditions without much exaggeration.

What to do about it is clear enough. The most effective measures are well known. Eventually they bring results, even though progress is always retarded by those money-lenders and others who oppose regulation. By means of these measures, for more than a generation the loan sharks have been driven out of one stronghold after another, and rarely have they regained any lost ground. Recently, they lost Minnesota and California; before long they will lose Texas, 'Washington, and Florida; few lucrative regions will be left.

To help the good work along, the licensed lenders can do even more than they have done in the past. They can strengthen their national association and bring more pressure to bear on the minority of recalcitrant members-the kind that bring discredit to every trade association. The licensed lenders in every well-regulated state can maintain even more effective state associations than they now have, for the purpose of lifting the business to the high level of their adopted codes of ethics; for the further purpose of telling the people all there is to know about the present status of a business with a bad past, concerning which so much is now believed which is not so. The cause of rigorous and wise regulation can gain even more effective aid from better business bureaus, legal aid societies, university departments of economics and of sociology, and social workers generally; for these agencies, once fully informed, are always on the right side. For them to support the best small loan laws and oppose all others is directly in line of duty. In the past, the licensed lenderssometimes from necessity, no doubt-have had too much of this work to do. Still further to consolidate their gains and discourage unwise legislation, the licensed lenders, collectively, can do more than they have yet done toward increasing the number of loans in the smaller brackets, and toward decreasing the kind of advertising which creates ill-will toward their business. All these measures are as good for the borrowers and for the public as they are for the lenders.

${ }^{25}$ This applies only to effectiveness of regulation under the Uniform Small Loan Law. Several states which control lenders who are licensed under this law have other laws under which anti-social lending is widely carried on. See Hubachek supra p. 127. 